Acta vet. scand. $1984,25,50-56$.

From the Finnish Fur Breeders Association, Vantaa, and the National Veterinary Institute, Helsinki, Finland.

\title{
THE INFLUENCE OF THE HEMOGLOBIN CONCENTRATION IN GROWING MINK KITS ON CERTAIN SKIN CHARACTERISTICS
}

\author{
By \\ Anne Näveri, Jouni Kangas and Jaakko Mäkelä
}

\begin{abstract}
NÄVERI, ANNE, JOUNI KANGAS and JAAKKO MÄKELÄ: The influence of the hemoglobin concentration in growing mink kits on certain skin characteristics. Acta vet. scand. 1984, 25, 50-56. - The relationship between some skin characteristics and hemoglobin values during the growth period were statistically examined in standard male minks. Significant correlations $(P<0.05-0.001)$ were found between the hemoglobin concentrations determined at 3 points during the growth period (in July, August and November) and the density and colour of underfur, and skin length, respectively. According to the study even the early hemoglobin values in July and August have a significant influence on the size and quality of the pelt. Mink kits with low hemoglobin values are liable to develop a winter fur coat with defective pigmentation and hair structure of the underfur. Anemic minks develop the most extreme stage of the pigmentation defect and these so-called cotton fur skins have little value in the fur garment industry. When these abnormal hemoglobin values are recognized at an early stage, cotton fur skins may be avoided, and larger skins of better quality may be produced.
\end{abstract}

hemoglobin concentration; mink; skinsize; skin quality; cotton fur.

Growing minks suffering from anaemia during the autumn months are highly susceptible to develop the so-called cotton-fur defect in the prime winter coat (Helgebostad et al. 1961). In cotton-fur defect, the underfur is thin and partially or totally depigmentated, while the guard hair may be normal in structure and pigmentation (Stout et al. $1960 \mathrm{a}, \mathrm{b}$ ).

According to several investigators, the most common cause of mink anaemia and the subsequent pigmentation defect of the underfur is iron deficiency (Helgebostad \& Martinsons 1958, Havre et al. 1967, Costley 1970, Löliger 1970, Skrede 1970, Helgebostad 1981). 
Helgebostad (1961) found that cotton fur inevitably develop in minks if the hemoglobin concentration falls below $130 \mathrm{~g} / \mathrm{l}$ during September. Very low hemoglobin values also lead to retarded growth, high mortality, and poor fur quality (Helgebostad \& Martinsons 1958, Stout et al. $1960 \mathrm{a}, \mathrm{b}$, Helgebostad \& Ender 1961, Jørgensen \& Christensen 1966). Depigmentation of underfur is also seen in other nutritional deficiencies and in the presence of certain antimetabolites in the feed. In these cases the animals are not always anaemic (Helgebostad 1957, Wehr et al. 1979).

The purpose of the present study was to examine the possible influence of the hemoglobin concentration in growing standard male minks on certain skin characteristics, including the colour and density of the underfur and skin length. Another purpose of the work was to study the relationship between body growth and hemoglobin values during the growth period, as well as the correlations between certain skin characteristics and body growth.

\section{MATERIAL AND METHODS}

The study was based on the data from various feeding experiments carried out on the research farm of the Finnish Fur Breeders Association. The material includes the data from 695 standard male mink kits in $\mathbf{1 6}$ different experimental or control groups during the growth periods in the years 1966-1969.

The minks were weighed at the beginning of July and again in November prior to pelting. The body growth of each individual was calculated. Blood samples were taken 3 times during the growth period: in the second week of July, late August, and at the beginning of November. For practical reasons, the sampling date was not identical for all individuals but varied by a few days. The blood kas collected by cutting a toe nail. The hemoglobin concentrations were determined using a Spencer Hemoglobinometer (American Optical Co., Buffalo, USA) by the oxyhemoglobin method (Schalm et al. 1975).

The pelts were graded and classified according to the following skin parameters: density of underfur, colour of underfur, and skin length. The density and colour of the underfur were assessed visually by experienced skin sorters. The skins were classified according to a scale from 1 to 10 , the highest points being given to skins of dense texture with dark-coloured underfur. The length of each skin was measured from the nose to the base of the tail. 
The data was registered on an individual basis and correlations computed between the measured skin parameters or "variables" (Statistical Computer Programme, IBM). Simultaneously, a basic statistical analysis was performed, where the mean value, variance, and standard deviation (s) were calculated for each variable according to Snedecor \& Cochran (1967).

It has to be emphasized that the animals were not of exactly the same age when weighed or analysed for the hemoglobin concentration each year. In addition, the mink stock of the farm comprised several genetic strains and was fed different ratios during the growth period. All these factors have obviously had an effect on the mean values and other summary statistics of the parameters. For example, some of the experimental diets were anaemiogenic and resulted in retarded growth and short, poor-quality skins.

\section{RESULTS}

The results of the basic statistical analysis on 9 variables are presented in Table 1 . The mean weight in July was $646 \mathrm{~g}$ and the standard deviation was $23.5 \%$ of the mean. The mean November

T a b l e 1. Basic statistics on the weights, hemoglobin concentrations and skin values of standard male minks $(n=695)$.

\begin{tabular}{|c|c|c|c|c|}
\hline Variable & Unit & Mean & Variance & $\mathbf{s}$ \\
\hline Weight in July & $\mathrm{g}$ & 646 & 23132.5 & 152.1 \\
\hline November & , & 1857 & 114786.8 & 338.8 \\
\hline $\begin{array}{l}\text { Body growth } \\
\text { Hemoglobin values }\end{array}$ & , & 1211 & 84874.7 & 291.3 \\
\hline in July & $\mathrm{g} / \mathrm{l}$ & 134 & 16.7 & 12.9 \\
\hline in August & , & 162 & 33.6 & 18.3 \\
\hline in November & , & 176 & 35.0 & 18.7 \\
\hline Underfur density & points & 6.9 & 4.70 & 2.17 \\
\hline colour & , & 5.5 & 5.73 & 2.39 \\
\hline Skin length & $\mathrm{cm}$ & 65 & 26.0 & 5.1 \\
\hline
\end{tabular}

weight was $1875 \mathrm{~g}$ with a standard deviation of $18.2 \%$ of the mean. The mean body growth of the 695 mink kits was calculated to be $1211 \mathrm{~g}$.

The mean values of the 3 hemoglobin measurements were $134 \pm 13 \mathrm{~g} / \mathrm{l}, 162 \pm 18 \mathrm{~g} / \mathrm{l}$, and $176 \pm 19 \mathrm{~g} / \mathrm{l}$, respectively. The standard deviations werc rather moderate, $10-11 \%$ of the means. 
T a b l e 2. Correlations between weights, hemoglobin concentrations, and certain skin characteristics of standard male minks $(n=695)$.

\begin{tabular}{|c|c|c|c|c|c|c|c|c|c|}
\hline & \multicolumn{2}{|c|}{ Weight in } & \multirow{2}{*}{$\begin{array}{l}\text { Body } \\
\text { growth }\end{array}$} & \multicolumn{3}{|c|}{ Hemoglobin values in } & \multicolumn{2}{|c|}{ Underfur characteristics } & \multirow{2}{*}{$\begin{array}{l}\text { Skin } \\
\text { length }\end{array}$} \\
\hline & July & November & & July & August & November & Density & Colour & \\
\hline \multicolumn{10}{|l|}{ Weight in } \\
\hline July & 1.000 & $0.514^{\star \star \star}$ & 0.076 & $0.462^{\star \star \star}$ & $0.216^{\star \star \star}$ & $0.212^{\star \star \star}$ & 0.041 & 0.040 & $0.432^{\star \star *}$ \\
\hline November & & 1.000 & $0.894^{\star \star \star}$ & $0.244^{\star \star \star}$ & $0.305^{\star \star \star}$ & $0.384^{\star \star \star}$ & 0.007 & $0.221^{\star \star \star}$ & $0.885^{\star \star \star}$ \\
\hline Body growth & & & 1.000 & 0.043 & $0.2411^{\star \star \star}$ & $0.336^{\star \star \star}$ & -0.012 & $0.236^{\star \star \star}$ & $0.806^{\star \star \star}$ \\
\hline \multicolumn{10}{|l|}{$\begin{array}{l}\text { Hemoglobin } \\
\text { values in }\end{array}$} \\
\hline July & & & & 1.000 & $0.556^{\star \star \star}$ & $0.380^{\star \star \star}$ & $0.184^{\star \star}$ & $0.104^{\star}$ & $0.237^{* * *}$ \\
\hline August & & & & & 1.000 & $0.615^{\star \star \star}$ & $0.219^{\star \star}$ & $0.271^{*}$ * & $0.302^{* * *}$ \\
\hline November & & & & & & 1.000 & $0.332^{\star \star \star}$ & $0.334^{\star \star \star}$ & $0.391^{* * *}$ \\
\hline \multicolumn{10}{|c|}{$\begin{array}{l}\text { Underfur } \\
\text { characteristics }\end{array}$} \\
\hline Density & & & & & & & 1.000 & $0.244^{\star \star \star}$ & 0.022 \\
\hline Colour & & & & & & & & 1.000 & $0.233^{\star \star *}$ \\
\hline
\end{tabular}

Significance of the correlation coefficients:

* $\quad \mathrm{P}<0.05$

* * $\quad \mathrm{P}<0.01$

$\star \star \star \mathrm{P}<0.001$

The hemoglobin concentration in the mink is age-dependent, a fact which is also seen in this study: increasing hemoglobin values were obtained in successive blood samplings.

The mean value for skin length was $65 \pm 5 \mathrm{~cm}$.

The results obtained from the correlation analysis of the variables are presented in Table 2 as a correlation matrix. Statistically significant correlations are indicated. The analysis revealed highly significant correlations between most of the measured parameters.

Significant correlations were found between the body weights in July and November $(\mathrm{P}<0.001)$, and between the November weight and body growth $(\mathrm{P}<0.001)$. The 3 hemoglobin concentrations were all correlated with each other $(\mathrm{P}<0.001)$, as well as with the density and colour of the underfur, and with the skin length. The significant coefficients were the lowest for the hemoglobin value in July and underfur density $(\mathrm{P}<0.01)$, and underfur colour $(\mathrm{P}<0.05)$. The correlations between the skin characteristics and hemoglobin values increased during the 
growth period so that the highest coefficients between skin properties and hemoglobin concentrations were found in August and November $(P<0.001)$. The same trend was noticed towards higher coefficients between hemoglobin values and skin length with increasing age, although it was not so pronounced.

The body weight in July had no relationship with the colour or density of the underfur. However, the weight in November and body growth had a positive correlation to the colour $(\mathrm{P}<0.001)$, but not to the density of the underfur. Skin length correlated positively with all the other parameters $(P<0.001)$, except underfur density.

\section{DISCUSSION}

In severe cases of anaemia a tendency for fainter skin colour has been observed, even if cotton fur pelts have been excluded (Skrede 1970), but no connection between skin colour and hemoglobin concentration has been found in non-anaemic minks (Skrede 1971). Jorgensen \& Christensen (1966) stated that the hemoglobin concentration in August has no practical influence on the pigmentation degree of the underfur at the time of pelting. Contradictory results have also been published. Adair et al. (1975) observed that minks anaemic in August develop cotton fur skins in spite of recovering from the anaemia before pelting. The present study confirms the observation that hemoglobin values during the early growth period have an influence on growth, and later on underfur characteristics and skin length. In addition, the correlation matrix reveals that a low hemoglobin concentration already in July and August makes the animal more liable to develop a poor-quality skin than its counterpart with better blood values. This is partly in contradiction to some earlier studies (Jørgensen \& Christensen 1966), but is in agreement with the studies carried out by Adair et al. (1975). It should be noted that the large number of minks examined contributed to the significant correlations between underfur characteristics and hemoglobin concentrations. In previous studies, the material has been much smaller.

It would be of great economic interest to be able to predict the development of low-grade skins in the summer already. The diet could be controlled and extra iron supplied to the minks early enough to prevent the digressive trend before the kits become anaemic. 


\section{ACKNOWLEDGEMENT}

The study was financially supported by the Helve Foundation.

\section{REFERENCES}

Adair, J., N.B. Wehr \& J. E. Oldfield: Effects or oral iron supplementation (Hemax) on prevention of formaldehyde-induced and hakeinduced anaemia in mink. Mink Farmers Research Foundation Progress Report nr. 5. Milwaukee, USA 1976.

Costley, G. E.: Involvement of formaldehyde in depressed iron absorption in mink and rats fed Pacific hake (Merluccius productus). Abstracts of thesis for the Ph.D. degree, Oregon State University, Corvallis, USA 1970.

Havre, G. N., A. Helgebostad \& F. Ender: Iron resorption in fish-induced anaemia in mink. Nature 1967, 215, 187-188.

Helgebostad, A.: Fiskefôringens innflytelse på pelsutvikling og sunnhetstilstand hos mink. (The effect of feeding fish on the development of fur coat and the health condition of the mink). Norsk Pelsdyrblad 1957, 31, 114-122.

Helgebostad, A.: Fortsatte studier over fôringsbetinget anemi hos mink. (Continuous studies on the feed-dependent anaemia in the mink). Norsk Pelsdyrblad 1961, 35, 420—423, 429.

Helgebostad, A.: Anemi hos pelsdyr, årsaker og profylakse. (Anaemia in the fur-bearing animals, aetiology and prophylaxis). Norsk Veterinærtidskrift 1981, 93, 421—427.

Helgebostad, A. \& E. Martinsons: Nutritional anemia in mink. Nature 1958, 181, 1660-1661.

Helgebostad, A. \& F. Ender: Nursing anemia in mink. Acta vet. scand. 1961, 2, 236-245.

Helgebostad, A., B. Gjønnes \& R.“ R. Svenkerud: Fôringsanemi hos mink. (Nutritional anaemia in the mink). Nord. Vet.-Med. 1961, $13,593-603$.

Jørgensen, G. \& G. Christensen: Relationship between haemoglobin values and fur properties in mink. Nord. Vet.-Med. 1966, 18, 166 $-173$.

Löliger, H.-C.: Pelztierkrankheiten. (Diseases of fur animals). VEB Gustav Fischer Verlag, Jena 1970, 399 pp.

Schalm, O. W., N. C. Jain \& E. J. Carroll: Veterinary Hematology. 3rd ed. Lea \& Febiger, Philadelphia 1975, $807 \mathrm{pp}$.

Skrede, A.: Dietary blood in the prevention of fish-induced anemia in mink. II. Feeding experiments. Acta agric. scand. 1970, 20, 275 -285 .

Skrede, A.: Anemi hos pelsdyr - nyere resultater. (Anaemia in furbearing animals - recent results). Stensiltr. no. 27, Inst. for Fjørfe og Pelsdyr, Norges Landbruksh øgskole 1971, 17 pp.

Snedecor, G. W. \& W. G. Cochran: Statistical Methods. 6th ed. Iowa State University Press, Iowa 1967, 593 pp. 
Stout, F. M., J. E. Oldfield \& J. Adair: Aberrant iron metabolism and the "cotton fur" abnormality in mink. J. Nutr. 1960 a, 72, 46-52.

Stout, F. M., J. E. Oldfield \& J. Adair: Nature and cause of the "cotton fur" abnormality in mink. J. Nutr. $1960 \mathrm{~b}, 72,421-426$.

Wehr, N., J. Adair \& J. E. Oldfield: Effects on fur color. Blue Book of Fur Farming/US Fur Rancher 1979, pp. 40-43.

\section{SAMMANFATTNING \\ Inverkan av hemoglobinkoncentrationen på några pälsegenskaper hos växande minkvalpar.}

Förhållandet mellan vissa pälsegenskaper och hemoglobinvärden under växtperioden har undersökts statistiskt hos minkhanar av standard typ. Signifikanta korrelationer $(P<0.001-0.05)$ upptäcktes mellan hemoglobinkoncentrationerna vid tre tidspunkter (i juli, augusti och november) och bottenullens massa och färg samt skinnlängden. Enligt undersökningen är hemoglobinvärdena redan $i$ juli och augusti av stor betydelse på vinterpälsens längd och kvalitet med hänsyn till bottenullens massa och färg. Anemiska minkvalpar utvecklar en såkallad ,bomullspäls“ (cotton fur), vars värde i pälsindustrin är låg. Tendensen för dålig bottenull finns också hos valpar med subnormala hemoglobinvärden. När de låga hemoglobinkoncentrationerna uppmärksammas tidigt under växtperioden, kan utvecklingen av bomullspälsar undvikas och större skinn av bättre kvalitet produceras.

(Received January 11, 1984).

Reprints may be requested from: Anne Näveri, the Finnish Fur Breeders Association, P. O. Box 5, SF-01601 Vantaa, Finland. 